\title{
Microbiological Quality of Market Fruits and Their Handling Implication in Relation to Public Health
}

\author{
Mohammad Kamrul Alam, Mahbubul Pratik Siddique*, Muhammad Tofazzal Hossain, Md. Atawar Rahman and Md. Shahidur \\ Rahman Khan
}

Department of Microbiology and Hygiene, Bangladesh Agricultural University, Mymensingh-2202, Bangladesh

*Corresponding author's e-mail: mpsiddique77@gmail.com

[Received: 03 December 2012, Revised: 17 December 2012, Accepted: 24 December 2012]

\section{A B S T R A C T}

\begin{abstract}
The research study was conducted on the market fruits from selected local markets of Mymensingh, Bangladesh. The objectives of the study were to assess the microbiological quality of market fruits, hand washing and used water of hotels and chatpoti shops and to predict the comparative public health implication associated with the socioeconomic status of the inhabitants consuming the fruits and water. In fruit samples, the total viable count ranged from $\log 2.90$ to $\log 6.4$. No coliform bacteria were detected in fruit samples. Statistical analysis showed significant variations in microbial load in different fruits, hand washings and used water. Present study further demonstrated that there was lack of proper hygienic and sanitation measures in most of the markets, especially in town markets. Because of observed low sanitary quality, the urban market fruits should be handled and used with special attention to reduce the risk of contamination with potential pathogenic bacteria.
\end{abstract}

Keywords: Market Fruits, Microbial Quality, Hygienic Condition, TVC, TCC

(C) 2012 Microbes and Health. All rights reserved

\section{Introduction}

Fresh fruits and vegetables promote good health but harbor a wide range of microbial contaminations (Eni et al., 2010) Increasing health awareness has led to an increased consumption of minimally processed fruits in recent years (Warriner et al., 2009), as these do not require elaborate preparations (Amoah et $a l ., 2009)$. Microbial spoilage and contaminating pathogens pose a serious problem in food safety (Abadias, et al., 2008; Warriner et al., 2009). Fruits from sources like super markets may be protected from contamination and spoilage during subsequent handling, packaging, transport and storage (Park et al., 2012). Zweietering (2002) stated that four categories of Microbiological quality have been assigned based on standard plate counts, levels of indicator organisms and the number or presence of pathogens. These are satisfactory, marginal, unsatisfactory and potentially hazardous. Satisfactory results indicate good microbiological quality. No action required. Marginal results are borderline in that they are within limits of acceptable microbiological quality but may indicate possible hygiene problems in the handling of the fruits. Unsatisfactory results are outside of acceptable microbiological limits and are indicative of poor hygiene or food handling practices. Potentially hazardous, the levels in this range may cause food borne illness and immediate remedial action should be initiated Actions consideration should be given to the withdrawal of suspected fruits still available for sale or distribution and recall of marketed fruits.

To cite this article: Alam MK, MP Siddique, MT Hossain, MA Rahman and MSR Khan, 2012. Microbiological quality of market fruits and their handling implication in relation to public health. Microbes Health, 1(2): 76-80.
In Bangladesh, sellers as well as consumers are not well aware of the hygienic management in all steps of fruit production, processing, transportation, marketing and consumption (Rahman et al., 2011). Report on water used for the washing of fresh tomatoes in major markets in south-eastern Nigeria has been shown to possess a high level of microbial contamination (Ofor et al. (2009). Present study was undertaken to determine the bacterial load of fruits sold in retail market. We also aim to identify any potential pathogenic bacterial contamination and assess the situation in terms of public health hazard.

\section{Materials and Methods}

The study was conducted in the Bacteriology Laboratory of the Department of Microbiology and Hygiene, Faculty of Veterinary Science, Bangladesh Agricultural University (BAU), Mymensingh, Bangladesh, during the period from January to May, 2008.

\section{Sample collection and transportation}

Samples were collected from selected fruit markets of Mymensingh sadar upazila, following the methods described elsewhere (Andrews and Hammock, 2003). The fruit markets were KR market of BAU campus, Sheshmoor, Kewatkhali, Shambhugonj Bridge Bus Terminal and Ganginapar of Mymensingh. A total of 20 fruits ( 5 apples, 5 grapes, 5 tomatoes and 5 plum), 10 water samples (used water in hotel and chatpoti shop) and 5 samples of hand washing (from various fruit sellers) were collected from different markets.

\section{Preparation of culture media}

All the culture media [Nutrient Agar (NA), Blood Agar (BA), Eosin Mehtylene Blue (EMB), MacConkey's Agar (MA) and Salmonella and Shigella (SS) agar media] were prepared 
following the procedure described by BAM (2001) and Cheesbrough (2006).

\section{Processing of samples}

Proper care was taken during the sampling procedure to prevent contamination of the sample as per procedure described by Andrews and Hammock (2003). The fruit samples were washed with distilled water. The washed water was transferred into a separate tube containing $0.1 \%$ peptone solution. Used water samples including the hand washing water were directly inoculated $(0.5 \mathrm{ml})$ into $4.5 \mathrm{ml} 0.1 \%$ sterile peptone solution. The samples were then subjected to microbial assessment and analysis.

\section{Isolation of different bacteria from samples}

After collection of samples, 100 microliters of the processed sample were inoculated onto NA media and EMB agar media by spread plate technique. The inoculated media were incubated at $37^{\circ} \mathrm{C}$ for overnight in an incubator. Different types of bacterial colonies were counted and isolated in pure cultures

\section{Determination of total viable count (TVC)}

For the determination of total viable counts, $0.1 \mathrm{ml}$ of each ten fold dilution was transferred and spread on plate count (PC) agar using a sterile pipette for each diluent. The diluted samples were spread as quickly as possible on the surfaces of the plate with a sterile glass spreader. The plates were then kept in an incubator at $37^{\circ} \mathrm{C}$ for $24-48$ hours. Following incubation, plates exhibiting 30-300 colonies were counted. The average number of colonies in a particular dilution was multiplied by the dilution factor to obtain the total viable count. Total viable count was expressed as the number of organism of colony forming units per gram (CFU/ml) of samples (Cheesbrough, 2006; Garthright, 2001).

Determination of total coliform count (TCC)

For the determination of total coliform count the TVC method was employed. For TCC method MacConkey agar media and broths were used for bacterial propagation (Feng et al., 2002).

\section{Gram staining and motility test}

Gram staining and Motility test using hanging drop method were employed to provide basic information about the presumptive bacterial identification as suggested by Cheesbrough, (2006).

\section{Identification of the isolated bacteria}

\section{Culture into different media}

Sterilized platinum loops were used for streaking the culture on EMB agar, MacConkey agar and Salmonella-Shigella (SS) agar to get isolates in pure culture. All inoculated media were kept at $37^{\circ} \mathrm{C}$ for overnight in an incubator.

\section{Biochemical test}

Isolated organisms with specific characteristic on BA, SS, MC and EMB agar were subjected to biochemical tests. Standard methods were followed to conducting these tests according to the procedure of BAM (2001) and Cheesbrough (2006).

\section{Carbohydrate fermentation test}

The carbohydrate fermentation test was performed by inoculating a loop full of respective nutrient broth culture of the organisms into the tubes containing five basic sugars e.g., dextrose, sucrose, lactose, maltose and mannitol and incubated for $24 \mathrm{hrs}$ at $37^{\circ} \mathrm{C}$. Acid production was observed by the colour change from reddish to yellow in the medium and the gas production was noted by the presence of gas bubbles in the inverted Durham's tubes.

\section{Catalase test}

This test was used to differentiate bacteria, which produce the enzyme catalase, such as Staphylococci, from non-catalase ones such as Streptococci. To perform this test, a good growth culture of test organism was smeared with a sterile wooden stick or glass rod and was immersed into the $\mathrm{H}_{2} \mathrm{O}_{2}$ solution. If bubbles of oxygen are released, the organisms are considered catalase producers.

\section{MR-VP test}

For MR-VP tests, the tubes containing $2 \mathrm{ml}$ of MR-VP broth were inoculated with the isolated organism. Tubes for VP test were inoculated at $37^{\circ} \mathrm{C}$ for 24 hours but for 5 days at the same temperature for MR test. To perform VP test $1.2 \mathrm{ml}$ of $5 \%$ alkaloid alpha-naphthol and $0.2 \mathrm{ml}$ of $40 \% \mathrm{KOH}$ were added in each incubated VP test tube. The ingredients were mixed thoroughly and kept still. The appearance of pink color indicates its positive reaction for the presence of acetyl methyl- carbinol. The organism, isolated was found negative for VP test as the broth of $E$. coli culture produced yellow color when treated with the VP reagents. For MR test two to four drops of MR solution were poured in each tube. The appearance of red color was regarded positive and yellow color negative for MR test.

\section{Maintenance of stock culture}

For the maintenance of stock culture, $1 \mathrm{ml}$ of $80 \%$ sterilized glycerol was used in which $1 \mathrm{ml}$ of nutrient broth (NB) culture was mixed and stored at $20^{\circ} \mathrm{C}$.

\section{Results}

Total viable count (TVC) and total coliform count (TCC) in different samples

The TVCs of the apple washings from different market palaces are presented in Table 1 . The mean $\pm \mathrm{SD}$ value of total viable count was $\log 2.96 \pm 0.22$. The highest bacterial density was found $\log 3.14$ at Shambhugonj area and a significantly $(\mathrm{P}<0.01)$ lowest bacterial density at KR market $(\log 2.90)$. In $\mathrm{KR}$ market there was a good hygienic condition and in other areas the hygienic condition was moderate. There was a great effect of fruits hygienic condition on the total viable bacterial count. The mean TVC were $\log 2.97, \log 4.49$ and $\log 6.35$ for apple, tomato and plum, respectively. On the other hand, TVC in grapes were nil. This may be due to the sanitary, handling and preservation of grapes.

The bacterial density of tomato washing in different sample was significant at $1 \%$ level of probability (Table 1 ). The tomato of Sheshmoor with lower hygienic condition was evidenced consistently high $(\log 5.04)$, followed by Kewatkhali and Shambhugonj area ( $\log 4.38$ and 4.37 respectively). On the other hand, the lower bacterial load was observed at KR market area (log 4.34). Plum washing varied significantly $(\mathrm{P}<0.01)$ and are presented in Table 1 . The mean $\pm \mathrm{SD}$ value of total viable count (TVC) was $\log 6.36 \pm 0.052$. The bacterial load was highest (log 6.42) at Kewatkhali and the lowest bacterial density was log 6.29 at KR market

In case of hotel used water the highest TVC was found in Sheshmoor (log 6.26) and lowest was KR market (log 6.14). On the other hand used water in chatpoti shop the highest TVC was found in town $(\log 5.94)$ and lowest in BAU campus $(\log 5.83)$. In this study, TCC was nil in fruits (apple, grapes, tomato, pulm). This may be due to practice of good hygiene and sanitation. In this study, TCC were found in hand washing of all experimental area which was higher $(\log 3.20)$ in Shambhugonj and was lower $(\log 1.70)$ in KR market. Coliform was also detected in used water of chatpoti shop may be reasons of step from the production to consumption which may affect the microbial load.

\section{Isolation of different organisms in different media}

Gram's staining and motility test

In the present study, on NB inoculation, all the organisms produced turbidity after $24 \mathrm{hrs}$ incubation at $37^{\circ} \mathrm{C}$. E. coli produced colorless colonies with hemolysis on BA, bright pink or red colonies on $\mathrm{MC}$ agar, greenish-black colonies with metallic sheen on EMB agar and slight pinkish colony on SS agar. In Gram's staining under microscope the organism 
Table 1. TVC and TCC of different fruits and their handling implications.

\begin{tabular}{|c|c|c|c|c|c|c|c|c|c|}
\hline \multirow[t]{2}{*}{ Sources } & \multicolumn{3}{|l|}{ Apple } & \multicolumn{3}{|l|}{ Tomato } & \multicolumn{3}{|l|}{ Pulm } \\
\hline & Hygiene status & TVC & TCC & Hygiene status & TVC & TCC & Hygiene status & TVC & TCC \\
\hline KR market & Good & 2.60 & Nil & Good & 4.34 & Nil & Good & 6.29 & Nil \\
\hline Sheshmoor & Lower & 3.08 & Nil & Lower & 5.04 & Nil & Lower & 6.37 & Nil \\
\hline Kewatkhali & Lower & 3.11 & Nil & Lower & 4.38 & Nil & Lower & 6.42 & Nil \\
\hline Shambhugonj & Lower & 3.14 & Nil & Lower & 4.37 & Nil & Lower & 6.39 & Nil \\
\hline \multirow[t]{3}{*}{ Ganginapar } & Moderate & 2.90 & Nil & Moderate & 4.36 & Nil & Moderate & 6.32 & Nil \\
\hline & Mean \pm SD & \multicolumn{2}{|c|}{$2.96 \pm 0.22 * *$} & Mean \pm SD & \multicolumn{2}{|c|}{$4.49 \pm 0.303^{* *}$} & Mean \pm SD & \multicolumn{2}{|c|}{$6.358 \pm 0.052 * *$} \\
\hline & $\overline{\mathrm{LSD}}$ & 0.105 & & LSD & 0.514 & & LSD & 0.115 & \\
\hline
\end{tabular}

Table 2. Hygienic condition, TVC and TCC per $\mathrm{ml}$ of hand washing water from different fruit sellers and used water from various hotels and chatpoti shops

\begin{tabular}{|c|c|c|c|c|c|c|c|c|c|c|}
\hline \multirow{3}{*}{$\begin{array}{l}\text { Sources } \\
\text { Points }\end{array}$} & \multirow{2}{*}{\multicolumn{5}{|c|}{ Hand washing water }} & \multicolumn{5}{|c|}{ Used water } \\
\hline & & & & & & \multicolumn{3}{|c|}{ Hotel } & \multicolumn{2}{|c|}{ Chatpoti shop } \\
\hline & 1 & 2 & 3 & 4 & 5 & 6 & 7 & 8 & 9 & 10 \\
\hline Hygiene status & Good & $\begin{array}{l}\text { Moderat } \\
\mathrm{e}\end{array}$ & Lower & Lower & Lower & Good & $\begin{array}{l}\text { Moderat } \\
\mathrm{e}\end{array}$ & Lower & Good & Lower \\
\hline \multirow[t]{2}{*}{ TVC } & 4.83 & 4.98 & 5.32 & 6.18 & 5.90 & 6.14 & 6.19 & 6.26 & 5.83 & 5.94 \\
\hline & \multicolumn{5}{|c|}{ Mean $\pm \mathrm{SD}=5.44 \pm 0.58^{* *}, \mathrm{LSD}=0.715$} & \multicolumn{5}{|c|}{ Mean $\pm S D=6.072 \pm 0.1801^{* *}, \mathrm{LSD}=0.214$} \\
\hline \multirow[t]{2}{*}{ TCC } & 1.70 & 2.80 & 2.60 & 3.20 & 3.00 & Nil & Nil & Nil & 3.30 & 3.70 \\
\hline & \multicolumn{5}{|c|}{ Mean \pm SD $=2.66 \pm 0.58^{*}$, LSD $=1.547$} & \multicolumn{5}{|c|}{ Mean $\pm \mathrm{SD}=1.40 \pm 1.922^{\mathrm{NS}}, \mathrm{LSD}=\mathrm{NS}$} \\
\hline
\end{tabular}

All counts are expressed in logarithm** $=\mathrm{P}<0.01 \mathrm{NS}=$ Non-significant, $1=\mathrm{KR}$ market, $2=$ Sheshmoor, $3=$ Kewatkhali, $4=$ Shombhugonj, $5=$ ganginarpar, $6=\mathrm{KR}$ market, $7=$ Jabber's moor, $8=$ Sheshmoor, $9=\mathrm{BAU}$ campus, $10=$ Town

Table 3. The results of biochemical tests of different organism

\begin{tabular}{|l|c|c|c|c|c|c|c|c|}
\hline \multirow{2}{*}{ Name of the organism } & \multicolumn{9}{|c|}{ Fermentation properties with five basic sugar } & \multirow{2}{*}{ Catalase } & \multirow{2}{*}{ MR test } & \multirow{2}{*}{ VP test } \\
\cline { 2 - 6 } & $\mathrm{DX}$ & $\mathrm{ML}$ & $\mathrm{L}$ & $\mathrm{S}$ & $\mathrm{MN}$ & & & \\
\hline Escherichia coli & $\mathrm{AG}$ & $\mathrm{AG}$ & $\mathrm{AG}$ & $\mathrm{AG}$ & $\mathrm{AG}$ & + & + & - \\
\hline Staphylococcus spp & $\mathrm{A}$ & $\mathrm{A}$ & $\mathrm{A}$ & $\mathrm{A}$ & $\mathrm{A}$ & + & + & + \\
\hline Bacillus spp & $\mathrm{A}$ & $\mathrm{A}$ & $\mathrm{A}$ & $\mathrm{A}$ & $\mathrm{A}$ & + & + & + \\
\hline
\end{tabular}

$\mathrm{DX}=$ Dextrose, $\mathrm{ML}=$ Maltose, $\mathrm{L}=$ Lactose, $\mathrm{S}=$ Sugar, $\mathrm{MN}=$ Mannitol, $\mathrm{AG}=$ Acid and gas, $\mathrm{A}=$ Acid, $\mathrm{MR}=$ Methyl-Red and $\mathrm{VP}=\mathrm{Voges}-$ Proskauer

Table 4. Frequency distribution and percentage (\%) distribution of bacteria contaminating fruit samples, hand washings and used water from various hotels and chatpoti shops

\begin{tabular}{|l|l|l|l|l|l|l|}
\hline Serial No. & Bacteria isolated & No. of sample & Percentage & \multirow{2}{*}{$\begin{array}{l}\text { Chi squire test } \\
\left(\lambda^{2}\right)\end{array}$} & $\begin{array}{l}\text { Percentage (\%) } \\
\text { distribution }\end{array}$ \\
\cline { 3 - 4 } & & Examined & Isolated & & \multirow{4}{*}{$0.261^{\mathrm{NS}}$} & 53.48 \\
\cline { 3 - 5 } & Staphylococcus spp. & 25 & 23 & $92 \%$ & & 11.63 \\
\hline 02 & Escherichia spp. & 20 & 5 & $25 \%$ & & 23.26 \\
\hline 03 & Bacillus spp. & 20 & 10 & $50 \%$ & & 11.63 \\
\hline 04 & Non specific & 25 & 5 & $20 \%$ & & \\
\hline & Total & 90 & 43 & $47.77 \%$ & & \\
\hline
\end{tabular}

NS $=$ Non-significant 
revealed Gram-negative, pink colour, small rod shaped arranged as single or paired. On NA media, Staphylococcus spp showed smooth circular, opaque often yellow-pigmented colony about 1 $\mathrm{mm}$ in diameter after $24 \mathrm{hrs}$ at $37^{\circ} \mathrm{C}$. Smears from pure cultures revealed Gram positive, round shaped bacteria arranged in cluster form. Bacillus spp. produced haemolytic zone on BA. In Gram's staining under microscope the organisms were shown Gram positive, rod shaped cells, arranged in chain form.

Distribution of selected bacteria present in different samples Most of the samples contained the Staphylococci (about 92\%) organisms. Bacillus spp. (50\%) ranks the second position and $E$. coli $(25 \%)$, the third position. In this study, non-specific organisms $(20 \%)$ were also found all of the experimental samples. The chi squire test found to be non-significant $(\mathrm{P}>0.05)$ which shown in Table 4 . A total of 43 bacterial isolates were recovered from different fruits samples. Out of isolated organism the ranking percentage was as follows; Staphylococcus spp. 53.48\%, Escherichia spp. 11.63\%, Bacillus spp. $23.26 \%$ and non specific $11.63 \%$.

\section{Discussion}

Total viable count (TVC) and total coliform count (TCC) in different samples

In the present study, TVC of bacteria in apple from Sheshmoor, Kewatkhali and Ganginapar, was moderate along with a lower to moderate fruit hygienic conditions. In all of the areas, TCC was nil and the hygienic conditions were good or lower moderate. Current data are in close agreement with the findings of Stopforth et al. (2004) which was log 3.0 in apple washing water. Rahman et al., (2011) reported on some commercially packed and fresh fruit juice from Dhaka city, Bangladesh and found that the TVC varied from $10^{2}$ to $10^{5} \mathrm{cfu} / \mathrm{ml}$ - the highest was $2.4 \times 10^{5} \mathrm{cfu} / \mathrm{ml}$. The also detected a large number of Staphylococci and Bacillus spp in some samples. The author also reported that total coliforms and fecal coliforms were found in six and five (out of fifteen) samples, respectively. Among total coliforms, Klebsiella, Enterobacter and E. coli were detected.

In this study, TCC was nil in fruits (apple, grapes, tomato and pulm). This may be due to practice of good hygiene and sanitation. Though, Nkere et al. (2011) stated that the level of coliform contamination in the food samples from vendors and restaurants (geometric mean count 7.64-9.21; MPN $>$ or $=50$ ) were above the accepted $10^{4} \mathrm{cfu} / \mathrm{g}$ or MPN $<$ or $=10$ limits. Orozco et al., (2008) found total coliform count $<05 \log$ CFU per tomato. Besides this Mukherjee et al., (2004) isolated 1.5 and 9.7 percent coliform from organic lettuce and organic green pepper respectively. Tsado et al. (2013) found bacterial load of $6.1 \times 10^{5} \mathrm{cfu} / \mathrm{g}$ with tomatoes of rural farms and rural markets whereas $4.5 \times 10^{5} \mathrm{cfu} / \mathrm{ml}$ with tomatoes of urban farms and markets.

In this study, TCC were found in hand washings of al experimental area - the highest (log 3.20) was from Shambhugonj and the lowest $(\log 1.70)$ was from KR market. Coliform was also found in used water of chatpoti shop. Shayo et al., (2007) found the TVC ranged from $2.75 \times 10(3)$ to $5.4 \times$ 10 (3) c.f.u/ml in used water in Tanzania which indicate poor quality in used water. Kroger and Noll (1969) found high proportion of $E$. coli and other coliform from washed water. On the contrary, Dragas and Tratnik (1975) found 2.3\% E. coli from used water. Delaquis et al., 2007 isolate E. coli from Japanese restaurant, fast food restaurant and western food restaurant in different cities of Taiwan.

Isolation of different organisms in different media

In the present study, the morphology, staining, cultural and biochemical characteristics, showed by different bacteria, are almost similar with the reports of BAM (2001) and Cheesbrough (2006). On the basis of these findings, the bacteria were identified as Staphylococcus, Bacillus and E. coli. Some non-specific bacteria were also found in the present study.

In the present study, most of the samples contained the Staphylococci (about 92\%) organisms. Bacillus spp. (50\%) ranks the second position and E. coli $(25 \%)$, the third position. In this study, non-specific organism (20\%) was also found all of the experimental samples. The chi squire test found to be nonsignificant $(\mathrm{P}>0.05)$ which shown in Table 4. Eni et al. (2010) identified nine bacteria belonging to eight genera from 15 samples of different fruits and vegetables in Sango-Ota, Nigeria and stated that Staphylococcus aureus $(29.2 \%)$ was the most frequently isolated followed by Staphylococcus spp $(12.5 \%)$, Klebsiella spp (12.5\%) and Salmonella spp (12.5\%). Actinomycetes (4.2\%) and Escherichia coli $(4.2 \%)$ were the least frequently isolated. Mukherjee et al., (2004) conducted microbiological analyses of fresh fruits and vegetables produced by organic and conventional farmers to determine the coliform count and the prevalence of Escherichia coli and Salmonella spp. Ameyapoh et al. (2007) found Bacillus spp. involved in spoilage of tomato. Arthur et al. (2007) isolated Salmonella from fresh market tomatoes with no samples yielding Shigella or verotoxigenic $E$. coli.

Among the 43 bacterial isolates recovered from different fruits samples, the ranking percentage was Staphylococcus spp. $53.48 \%$, Escherichia spp. $11.63 \%$, Bacillus spp. $23.26 \%$ and non specific $11.63 \%$. Nkere et al. (2011) found E. coli and Klebsiella pneumoniae were the two major coliforms identified among 98 coliform isolates obtained from the various food samples, of which $78(79.6 \%)$ were assumed to be of human origin on account of their ability to grow at $44^{\circ} \mathrm{C}$.

\section{Conclusion}

From the present study, it may be concluded that the presence of microorganisms in fruits and used water from hotel and chatpoti shop has public health importance because it might play a role for the commencement of various enteric diseases in man. The results of the study, therefore, demands the stringent supervision and implementation of food-safety practices and regular education on food and personal hygiene among food vendors.

\section{References}

Abadias M, J Usall, M Anguera, C Solsona and I Viñas, 2008. Microbiological quality of fresh, minimally-processed fruit and vegetables, and sprouts from retail establishments. Int. J. Food Microbiol. 123(1-2): 121-129.

Ameyapoh Y, C de Souza and AS Traore, 2007. Hygienic quality of traditional processing and stability of tomato (Lycopersicon esculentum) puree in Togo. Bioresour. Technol. 20: 7-27.

Amoah P, P Drechsel, RC Abaidoo and EM Abraham, 2009. Improving food hygiene in Africa where vegetables are irrigated with polluted water. Regional Sanitation and Hygiene Symposium, 3-5 Nov. 2009, Accra, Ghana.

Andrews WH and TS Hammack, 2003. Food Sampling and Preparation of Sample Homogenate. In: Bacteriological Analytical Manual. Chapter 1. U.S. Food \& Drug Administration. Center for Food Safety \& Applied Nutrition.

Arthur L, S Jones, M Fabri and J Odumeru, 2007. Microbial survey of selected Ontario-grown fresh fruits and vegetables.

J. Food Prot.. 70(12): 2864-2867.

BAM, 2001. Bacteriological Analytical Manual. Online Revision. U.S. Food \& Drug Administration. Center for Food Safety \& Applied Nutrition.

Cheesbrough M, 2006. District Laboratory Practice in Tropical Countries. Part 2. $2^{\text {nd }}$ edition. Cambridge University Press, New York. USA. Pp: 45-62.

Delaquis P, S Bach and LD Dinu, 2007. Behavior of Escherichia coli $\mathrm{O} 157: \mathrm{H} 7$ in leafy vegetables. J. Food Prot. 70(8): 1966-1974. 
Dragas AZ and M Tratnik, 1975. On the value of examination of drinking water and swimming pools for the presence of enteropathogenic E. coli. Microbial Abst. 10(9): 10878.

Eni, AO, IA Oluwawemitan and OU Solomon, 2010. Microbial quality of fruits and vegetables sold in Sango Ota, Nigeria. African J. Food Sci. Vol 4.(5): xx-xx. Available online http://www.academicjournals.org/ajfs.

Feng P, SD Weagant, MA Grant and W Burkhardt, 2002. Enumeration of Escherichia coli and the Coliform Bacteria. In: Bacteriological Analytical Manual. Chapter 4. . U.S. Food \& Drug Administration. Center for Food Safety \& Applied Nutrition.

Garthright WE, 2001. Most Probable Number Determination from Serial Dilutions. In: Bacteriological Analytical Manual. Appendix II. Latest Revision. U.S. Food \& Drug Administration. Center for Food Safety \& Applied Nutrition.

Kroger E and J Noll, 1969. Result of well water examination in a second marsh community. Microbial. Abstr. Sec. 5(2): 1485.

Mukherjee A, D Speh, E Dyck and GF Diez, 2004. Preharvest evaluation of coliforms, Escherichia coli, Salmonella, and Escherichia coli $0157: \mathrm{H} 7$ in organic and conventional produce grown by Minnesota farmers. J. Food Prot. 67(5): 894-900.

Nkere CK, NI Ibe and CU Iroegbu, 2011. Bacteriological quality of foods and water sold by vendors and in restaurants in Nsukka, Enugu State, Nigeria: a comparative study of three microbiological methods. J Health Popul Nutr. 2011 Dec; 29(6):560-6.

Ofor MO, VC Okorie, II Ibeawuchi, GO Ihejirika, OP Obilo and SA Dialoke, 2009. Microbial Contaminants in Fresh Tomato Wash Water and Food Safety Considerations in South-Eastern Nigeria. Life Sci J., 1: 80-82

Orozco L, RL Rico and EF Escartín, 2008. Microbiological profile of greenhouses in a farm producing hydroponic tomatoes. J. Food Prot. 71(1): 60-65.

Park S, B Szonyi, R Gautam, K Nightingale, J Anciso and R Ivanek, 2012. Risk factors for microbial contamination in fruits and vegetables at the preharvest level: a systematic review. J Food Prot. 75(11):2055-81.

Rahman T, S Hasan and R Noor, 2011. An Assessment of Microbiological Quality of Some Commercially Packed and Fresh Fruit Juice Available in Dhaka City: A Comparative Study. Stamford J. Microbiol. July, (1): 13-18

Shayo NB, BE Chove, AB Gidamis and OB Ngoma, 2007. The quality of water in small community supplies of Kingolwira Village, Morogoro, Tanzania. Tanzan. Health Res. Bull. 9(1): $56-60$.

Stopforth JD, JS Ikeda, PA Kendall and JN Sofos, 2004 Survival of acid-adapted or nonadapted Escherichia coli O157:H7 in apple wounds and surrounding tissue following chemical treatments and storage. Int. J. Food Microbiol. 90(1): 51-61.

Tsado EK, OA Adesina and SB Oyeleke, 2013. A Survey on the Bacterial Load of Selected Fruits and Leafy Vegetables in Minna Metropolis of Niger State, Nigeria. J Anim Prod Adv., 3(1): 6-11

Warriner K, A Huber, A Namvar, W Fan and K Dunfield, 2009. Recent advances in the microbial safety of fresh fruits and vegetables. Adv Food Nutr Res. 57:155-208.

Zweietering MH, 2002. Quantification of microbial quality and safety in minimally processed food. Int. Dairy J. 12: 263-271. 